\title{
Expression of the pro-opiomelanocortin gene in dorsal root ganglia, spinal cord and sciatic nerve after sciatic nerve crush in the rat
}

\author{
L.C. Plantinga ${ }^{\text {a }}$, J. Verhaagen ${ }^{\text {a }}$, P.M. Edwards ${ }^{\text {b }}$, L.H. Schrama ${ }^{\text {c }}$, J.P.H. Burbach ${ }^{\text {a }}$ \\ and W.H. Gispen ${ }^{\text {a }}$ \\ ${ }^{a}$ Rudolf Magnus Institute, Department of Pharmacology, Utrecht University, Utrecht (The Netherlands), ${ }^{b}$ Molecular Genetics Unit, \\ Bacteriology Department, Ministry of Agriculture, Fisheries and Food, Central Veterinary Laboratory, New Haw, Weybridge, Surrey (UK) \\ and ${ }^{c}$ Laboratory for Physiological Chemistry, Utrecht (The Netherlands)
}

(Accepted 7 July 1992)

Key words: Melanocortin; Pro-opiomelanocortin; Regeneration; Polymerase chain reaction; Northern blot analysis

\begin{abstract}
Neuropeptides related to $\alpha$-melanocyte-stimulating hormone ( $\alpha$-MSH) stimulate nerve outgrowth following peripheral nerve injury and may play an important physiological role in peripheral nerve regeneration. The mechanism of action underlying the neurotrophic effect of pharmacologically administered $\alpha$-MSH is unknown. Here we investigate the hypothesis that reexpression of the proopiomelanocortin (POMC) gene, the prohormone of $\alpha-\mathrm{MSH} /$ adrenocorticotropic hormone (ACTH)-like peptides, is part of the endogenous repertoire of peripheral nerve responses following injury. The effect of sciatic nerve crush on the expression of POMC mRNA between $0.5 \mathrm{~h}$ and 14 days after crush was investigated using polymerase chain reaction (PCR) and Northern blot analysis. The presence of a POMC transcript in dorsal root ganglia (DRG), spinal cord and in the sciatic nerve at the crush site could be demonstrated in both control and lesioned animals by PCR using primers located in exon 1 and 3 of the POMC gene. Minute quantities of two POMC transcripts (1200 nt and $800 \mathrm{nt}$ ) could be detected by Northern blot analysis of total RNA prepared from DRG, spinal cord and the sciatic nerve of control animals and of animals subjected to nerve crush. POMC mRNA expression was, however, not increased following nerve crush. Probes specific for exons 1 and 2 or specific for exon 3 of the POMC gene were employed to demonstrate that the $800 \mathrm{nt}$ transcript represents the truncated POMC mRNA previously shown to be present in extra-pituitary tissue. The larger $1200 \mathrm{nt}$ transcript comigrates with the full length POMC mRNA expressed in the pituitary gland. The present results demonstrate the expression of small amounts of POMC mRNA in all compartments of the sciatic nerve. The absence of an induction of POMC expression in response to nerve crush suggests that the stimulating effect of exogenously applied $\alpha$-MSH does not mimic a POMC derived neurotrophic peptide induced in the nerve following nerve injury.
\end{abstract}

\section{INTRODUCTION}

It has been shown by several laboratories that peptides related to adrenocorticotropic hormone (ACTH) and $\alpha$-melanocyte-stimulating hormone ( $\alpha$-MSH), collectively termed melanocortins, stimulate the recovery of peripheral nerves after crush lesion ${ }^{2,28,33}$. This neurotrophic action of melanocortins becomes apparent in an acceleration of functional recovery and an increase in the number of regenerating nerve fibres following nerve crush. The mechanism of action by which melanocortins exert these beneficial pharmacological effects is currently not known.

Melanocortins are normally formed from the prohormone pro-opiomelanocortin (POMC) by proteolytic cleavage. This precursor gives rise to a number of peptides including $\alpha$-MSH and $\beta$-endorphin. POMCderived peptides are predominantly formed in the pituitary gland and in the brain. In addition to these classical sites of POMC expression, other cell types have the capability to express the POMC gene. These include the gastrointestinal tract, gonads, thymus and the placenta ${ }^{6,7,26}$. Extra-pituitary expression of the POMC gene often leads to a short transcript of approximately $800 \mathrm{nt}$, as compared with the $1200 \mathrm{nt}$ mRNA found in the pituitary gland. This truncated POMC transcript lacks exons 1, 2 and the $5^{\prime}$ end of exon 3 and is most likely not functional as messenger RNA ${ }^{16,18}$.

Endogenous $\mathrm{MSH}$-like peptides may be formed in traumatized nerves in response to peripheral nerve 
injury as one of a cocktail of neurotrophic substances synthesised. Using a bioassay for $\alpha$-MSH, Edwards ${ }^{10}$ has presented evidence that an $\alpha$-MSH-like peptide may be present in degenerating nerve stumps 6 days after nerve damage. The presence of $\alpha-\mathrm{MSH}-$ and $\beta$-endorphin-like immunoreactive material was demonstrated in nerves following nerve transection ${ }^{14}$. In contrast to these findings, using a radioimmunoassay for $\alpha$-MSH, we were unable to detect $\alpha$-MSH immunoreactive material in the proximal and distal nerve stumps of degenerating peripheral nerves 3 and 5 days following nerve injury ${ }^{32}$. Carr and Haynes have demonstrated that the POMC gene is expressed in the developing spinal cord of E13 rat embryos and downregulated at E15 $5^{4}$. Moreover, in dystrophic mice ${ }^{13}$ and in mice with motoneurone disease ${ }^{15}$ immunoreactivity for POMC-derived peptides is present in a large portion of the motoneurones of the adult mice. Muscular dystrophy has been described as a condition where the maturation of the muscle endplate is delayed.

The objective of the present study was to examine in detail the expression of the POMC gene following injury to the sciatic nerve in order to elucidate whether upregulation of POMC gene expression is part of an endogenous series of events that occur in a nerve following injury. To this end POMC mRNA expression was examined at various timepoints after crush in DRG $\left(\mathrm{L}_{4-6}\right)$ and in the spinal cord $\left(\mathrm{T}_{12}-\mathrm{L}_{1}\right)$ containing respectively the cell bodies of the sensory neurons and the motoneurones of the sciatic nerve. It has been reported that mononuclear blood cells are capable of producing POMC related peptides ${ }^{11,23}$. Since macrophages are known to infiltrate the crush site after damage $^{24}$, we investigated the presence of POMC transcripts in this area as well. The POMC mRNA expression was compared to the expression of mRNA of B-50 (GAP-43), a well characterized growth associated protein $^{1,25,31,34}$ of which the expression responds to sciatic nerve injury.

\section{MATERIALS AND METHODS}

\section{Animals, surgery and tissue dissection}

Male Wistar rats (120-140 g, TNO, Zeist, The Netherlands) were used in all experiments. Rats were anaesthetized with Hypnorm (Duphar, Weesp, The Netherlands) at a dose of $0.8 \mathrm{ml} / \mathrm{kg}$ body weight. The right and the left sciatic nerves were crushed $27 \mathrm{~mm}$ distal to the sciatic notch with haemostatic forceps as described in detail by De Koning ${ }^{5}$. This procedure results in degeneration of all axons distal to the crush site. The position of the distal border of the $2.0 \mathrm{~mm}$ long crush lesion was marked by placing an epineural suture (Ethicon 6.0) in the epineurium to identify the precise position of the crush site. At 0.5 and $6 \mathrm{~h}$ and 1, 2, 4 and 14 days after crush the animals were sacrificed by decapitation. Unoperated age-matched animals were used as controls.

After decapitation the left and right dorsal root ganglia $\left(\mathrm{L}_{4-6}\right)$ and the spinal cord $\left(\mathrm{T}_{12}-\mathrm{L}_{1}\right)$ were dissected. In order to obtain a sufficient amount of RNA, DRGs of 3 animals were pooled for RNA isolation. From both sciatic nerves a $14-\mathrm{mm}$ piece of nerve was dissected $7 \mathrm{~mm}$ proximal and distal from the suture. The sciatic nerve pieces of 2 rats were pooled for RNA isolation. All tissues were stored at $-80^{\circ} \mathrm{C}$ until further processing. Gloves were worn at all times and dissection instruments were sterilized before the dissection of each rat. The pituitary gland and the hypothalamus (positive controls) were always dissected apart from the other tissues.

\section{$R N A$ isolation}

Total RNA was prepared by a single step method using RNAzol (Cinna/Biotecx, Friendswood, USA), a guanidinium isothiocyanate/ phenol based extraction solution according to the manufacturers instructions. In short, the tissue samples were homogenized in RNAzol $(2 \mathrm{ml} / 100 \mathrm{mg}$ tissue $)$ in a glass tube with a tightly fitting teflon pestle by 10 strokes up and down. Per $2 \mathrm{ml}$ of homogenate $0.2 \mathrm{ml}$ chloroform was added, shaken vigorously and put on ice. After centrifugation $\left(12,000 \times \mathrm{g}, 15 \mathrm{~min}, 4^{\circ} \mathrm{C}\right)$, the upper aqueous phase containing the RNA was transferred to a fresh tube and an equal volume of isopropanol was added. The RNA was allowed to precipitate for at least $45 \mathrm{~min}$ at $-20^{\circ} \mathrm{C}$. RNA was pelleted by centrifugation $\left(12,000 \times \mathrm{g}, 20 \mathrm{~min}, 4^{\circ} \mathrm{C}\right)$ and washed twice with $70 \%$ ethanol. The pellet was briefly dried in vacuo and dissolved in sterilized water. The amount of RNA was determined spectrophotometrically by $U V$ absorption at $A_{260}$, the purity was assessed via the $A_{260} / A_{280}$ ratio and the integrity was examined on a $2 \%$ agarose gel stained with ethidium bromide. The RNA was used for Northern blots or served as template for the production of cDNA for PCR. Because the PCR method is very sensitive to cross contamination, precautions to avoid false positives were taken during the preparation of the RNA. A fresh sterilised pestle was used for each sample and RNA from spinal cord, DRG and sciatic nerve was not isolated on the same day as RNA from the hypothalamus and the pituitary gland (positive controls).

For the poly $\left(\mathrm{A}^{+}\right)$RNA isolation, oligo-(dT)-cellulose type 3 (Collaborative Research, Bedford, MA, USA) was hydrated in a 10to 20 -fold excess of elution buffer $(0.01 \mathrm{M}$ Tris- $\mathrm{HCl}, \mathrm{pH} 7.5)$. The resin was pelleted by centrifugation $(2000 \times g, 5 \mathrm{~min})$, resuspended in $0.1 \mathrm{~N} \mathrm{NaOH}$ and incubated at room temperature for $20 \mathrm{~min}$. This was followed by one wash of elution buffer and several washes with binding buffer $(0.01 \mathrm{M}$ Tris- $\mathrm{HCl} \mathrm{pH} 7.5,0.5 \mathrm{M} \mathrm{NaCl})$ to remove the $\mathrm{NaOH}$ and to equilibrate the resin. The cellulose was finally resuspended in binding buffer at $40 \mathrm{mg} / \mathrm{ml}$. Two $\mathrm{mg}$ of total RNA from the spinal cord of 10 control rats isolated as described was dissolved in $5 \mathrm{ml}$ binding buffer after precipitation. An aliquot of resuspended resin corresponding to $50 \mathrm{mg}$ dry resin per $\mathrm{mg}$ total RNA was added and incubated for $30 \mathrm{~min}$ at room temperature with gentle mixing on a rocker platform. The resin was transferred to a polypropylene Econo-column (Bio-Rad Laboratories, Richman, CA, USA) that had been prewashed with $0.1 \mathrm{M} \mathrm{NaOH}$ followed by several washes with binding buffer. The resin was rinsed 4 to 5 times with binding buffer till the $\mathrm{A}_{260}$ was less than 0.05 . The poly $\left(\mathrm{A}^{+}\right) \mathrm{RNA}$ was eluted from the resin with 3 times $500 \mu \mathrm{l}$ of elution buffer. The washes were combined and the amount of poly $\left(\mathrm{A}^{+}\right)$RNA was determined spectrophotometrically.

\section{cDNA synthesis}

Single-stranded cDNA was synthesised from $10 \mu \mathrm{g}$ total RNA per sample. The RNA was denatured at $65^{\circ} \mathrm{C}$ for $5 \mathrm{~min}$ and put on ice. cDNA synthesis was carried out in $20 \mu \mathrm{l}$ of $1 \times$ first strand buffer $(50 \mathrm{mM}$ Tris- $\mathrm{HCl} \mathrm{pH} 7.6,70 \mathrm{mM} \mathrm{KCl}, 10 \mathrm{mM} \mathrm{MgCl} 2,4 \mathrm{mM}$ dithiotreit), $1 \mathrm{mM}$ of each dNTP, $3 \mu \mathrm{M}$ random primers, $20 \mathrm{U}$ RNAsin and $40 \mathrm{U}$ Moloney Murine Leukaemia Virus (MMLV) reverse transcriptase (Pharmacia, Uppsala, Sweden) for $2 \mathrm{~h}$ at $37^{\circ} \mathrm{C}$.

\section{Polymerase chain reaction}

Both the sense and the antisense primers for POMC and B-50 were 24 -mers. The sequence of the $5^{\prime}$ primer complementary to a sequence in exon 1 of the rat POMC gene starting at position 74 is 5'CAGAGAGCTCCCTTTCCGGCGACAG3' (primer A, Fig. 1) and the sequence of the $3^{\prime}$ primer complementary to exon 3 of the 


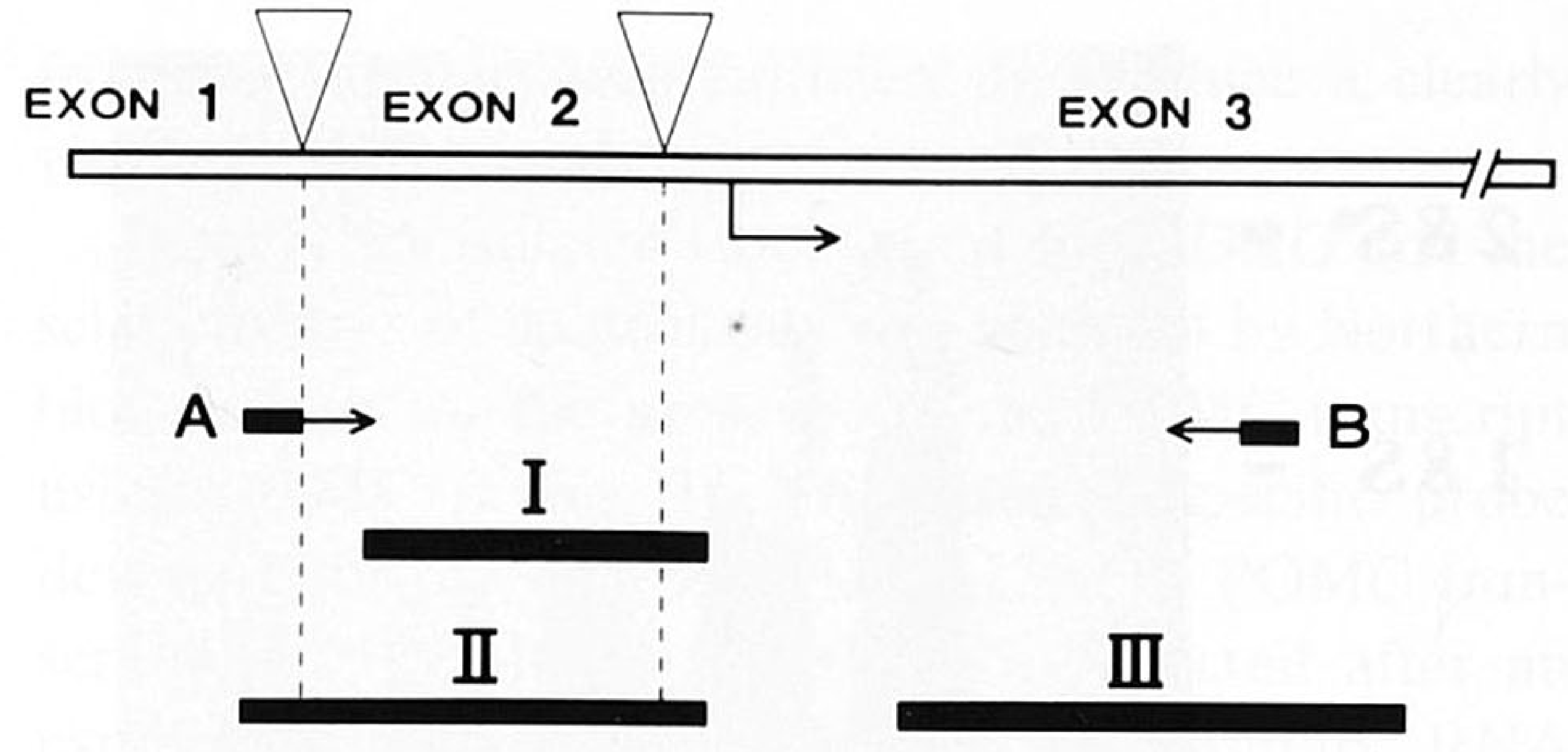

Fig. 1. Schematic representation of POMC mRNA showing the locations of the $5^{\prime}$ primer (A) and the $3^{\prime}$ primer (B) used in the PCR, the probe used for Southern blot hybridization (I) and two different probes used for Northern blot hybridization (II, III). The triangles indicate the position of the introns at nucleotide 98 and at nucleotide 248.

POMC gene starting at position 484 is 5'GGAAGAGCTCCATGGAGTAGGAGC3' (primer B, Fig. 1). The expected size of the amplification product is $433 \mathrm{bp}$. The sequence of the $5^{\prime}$ B-50 primer complementary to a sequence in exon 1 starting at position 41 is 5'AGCTGTGCTGTATGAGAAGAACC 3 ' and the sequence of the $3^{\prime}$ B-50 primer complementary to a sequence in exon 2 starting at position 265 is $5^{\prime}$ CCCTCCTTCTTCTCCACACCATCA3'. The expected size of the amplification product is $247 \mathrm{bp}^{22}$. Both sets of primers were used together in a single PCR. The cDNA equivalent to $1 \mu \mathrm{g}$ total RNA was amplified by PCR in a final volume of $50 \mu \mathrm{l}$. The PCR mixture contained 1x PCR buffer ( $10 \mathrm{mM}$ Tris- $\mathrm{HCl}$ pH 8.3 , $50 \mathrm{mM} \mathrm{KCl}, 1.5 \mathrm{mM} \mathrm{MgCl} 2,0.01 \%$ gelatin), $0.2 \mathrm{mM}$ of each dNTP (Pharmacia, Inc., Pitscataway, NJ), $1 \mu \mathrm{M}$ of each primer, and $2.5 \mathrm{U}$ of TAQ polymerase (Pharmacia). An intelligent heating block (Hybaid Ltd., Teddington, UK) was used to cycle the temperature of the samples. Samples were denatured for $10 \mathrm{~min}$ at $100^{\circ} \mathrm{C}$ and quickly cooled on ice prior to the addition of Taq polymerase and dNTP. Samples were overlaid with $50 \mu \mathrm{l}$ mineral oil and incubated for 30 cycles as follows: $94^{\circ} \mathrm{C}$ for $1 \mathrm{~min}, 55^{\circ} \mathrm{C}$ for $1 \mathrm{~min}$, and $72^{\circ} \mathrm{C}$ for $2 \mathrm{~min}$. After the last cycle the samples were incubated at $72^{\circ} \mathrm{C}$ for $10 \mathrm{~min}$ and stored at $-20^{\circ} \mathrm{C}$ until analysis. To avoid cross-contamination the following measures were $\operatorname{taken}^{36}$ : (1) positive displacement pipettes were used throughout the RNA isolation, the cDNA synthesis and PCR sample preparation, (2) preparation of PCR reaction mixtures, sample preparation and analysis of amplified products were each performed in separate rooms, (3) a negative control (complete PCR mixture containing water instead of template cDNA) was pipetted following each series of 7 samples during each experiment, (4) the positive controls (hypothalamus and pituitary cDNA) were always pipetted as the last sample of an experiment.

\section{Analysis of the PCR products}

The PCR products were separated on a $2 \%$ agarose gel prepared in TAE buffer ( $40 \mathrm{mM}$ Tris, $20 \mathrm{mM}$ acetate, $2 \mathrm{mM}$ EDTA pH 7.0) containing ethidium bromide $(0.4 \mu \mathrm{g} / \mathrm{ml})$. After electrophoresis and inspection of the gel under UV light, the agarose gel was placed in $0.25 \mathrm{M} \mathrm{HCl}$ for $30 \mathrm{~min}$ and rinsed in distilled water for $30 \mathrm{~min}$. Subsequently the PCR products were transferred to a nylon membrane (Zeta probe, Bio-Rad Laboratories, Richman, CA, USA) by capillary blotting in $0.4 \mathrm{~N} \mathrm{NaOH}$ overnight. The membrane was rinsed in $5 \times \mathrm{SSC}$ and prehybridized in $1.5 \times \operatorname{SSPE}(0.18 \mathrm{M}$ sodium chloride, $10 \mathrm{mM}$ sodium phosphate $\mathrm{pH}$ 7.0, $1 \mathrm{mM}$ EDTA), $1 \%$ SDS, $0.5 \%$ defatted milk powder (Refit, Campina, Eindhoven, The Netherlands) and $0.5 \mathrm{mg} / \mathrm{ml}$ denatured herring sperm DNA for $3 \mathrm{~h}$ at $70^{\circ} \mathrm{C}$. Hybridization was performed in the same solution with the addition of $10 \%$ dextran sulphate and $1 \times 10^{6} \mathrm{cpm} / \mathrm{ml}$ of a POMC cDNA fragment (probe I, Fig 1) ${ }^{32}$ P-labeled by random priming at $70^{\circ} \mathrm{C}$ overnight. The membranes were washed in $2 \times$ SSC, $0.1 \%$ SDS for $20 \mathrm{~min}$ at $50^{\circ} \mathrm{C}$ and finally in $0.1 \times \mathrm{SSC}, 1 \%$ SDS, $5 \mathrm{mM}$ EDTA for $10 \mathrm{~min}$ at $65^{\circ} \mathrm{C}$. The membranes were exposed to $\mathrm{X}$-ray film (Kodak, X-OMAT).

\section{Northern blot analysis}

For Northern blot analysis, total RNA was denatured with glyoxal and DMSO in $10 \mathrm{mM}$ phosphate buffer at $50^{\circ} \mathrm{C}$ for $60 \mathrm{~min}^{21}$. Subsequently samples were cooled on ice and run on $1 \%$ agarose gel in $10 \mathrm{mM}$ sodium phosphate, $\mathrm{pH} 7.0$, followed by capillary blotting to Nylon transfer membranes (Hybond N, Amersham UK) in $20 \times$ SSC. The membranes were exposed to UV light $(2 \mathrm{~min})$ and baked at $80^{\circ} \mathrm{C}$ for $2 \mathrm{~h}$. Membranes were prehybridized for $3 \mathrm{~h}$ at $42^{\circ} \mathrm{C}$ in hybridization solution containing $50 \mathrm{mM}$ Tris- $\mathrm{HCl} \mathrm{pH} 7.5,50 \%$ formamide, 1 $\mathrm{M} \mathrm{NaCl}, 10 \%$ dextran sulphate, $0.1 \mathrm{mg} / \mathrm{ml}$ denatured herring sperm DNA, $0.2 \%$ BSA, $0.2 \%$ polyvinylpyrrolidon, $0.2 \%$ ficoll, $0.1 \%$ sodiumpyrophosphate, $1 \%$ SDS. Hybridization was performed in the same buffer containing $1 \times 10^{6} \mathrm{cpm} / \mathrm{ml}$ of a POMC cDNA fragment (probe II and/or probe III, Fig 1) ${ }^{32}$ P-labeled by random priming. The high stringency washing procedure included the following steps: $5 \times$ SSC $0.1 \%$ SDS, $2 \times$ SSC $0.1 \%$ SDS, $1 \times$ SSC $0.1 \%$ SDS, $0.2 \times$ SSC $0.1 \%$ and $0.1 \times$ SSC $0.1 \%$ SDS. The low stringency protocol included: $5 \times$ SSC $0.1 \%$ SDS, $2 \times$ SSC $0.1 \%$ SDS, $1 \times$ SSC $0.1 \%$ SDS. In both

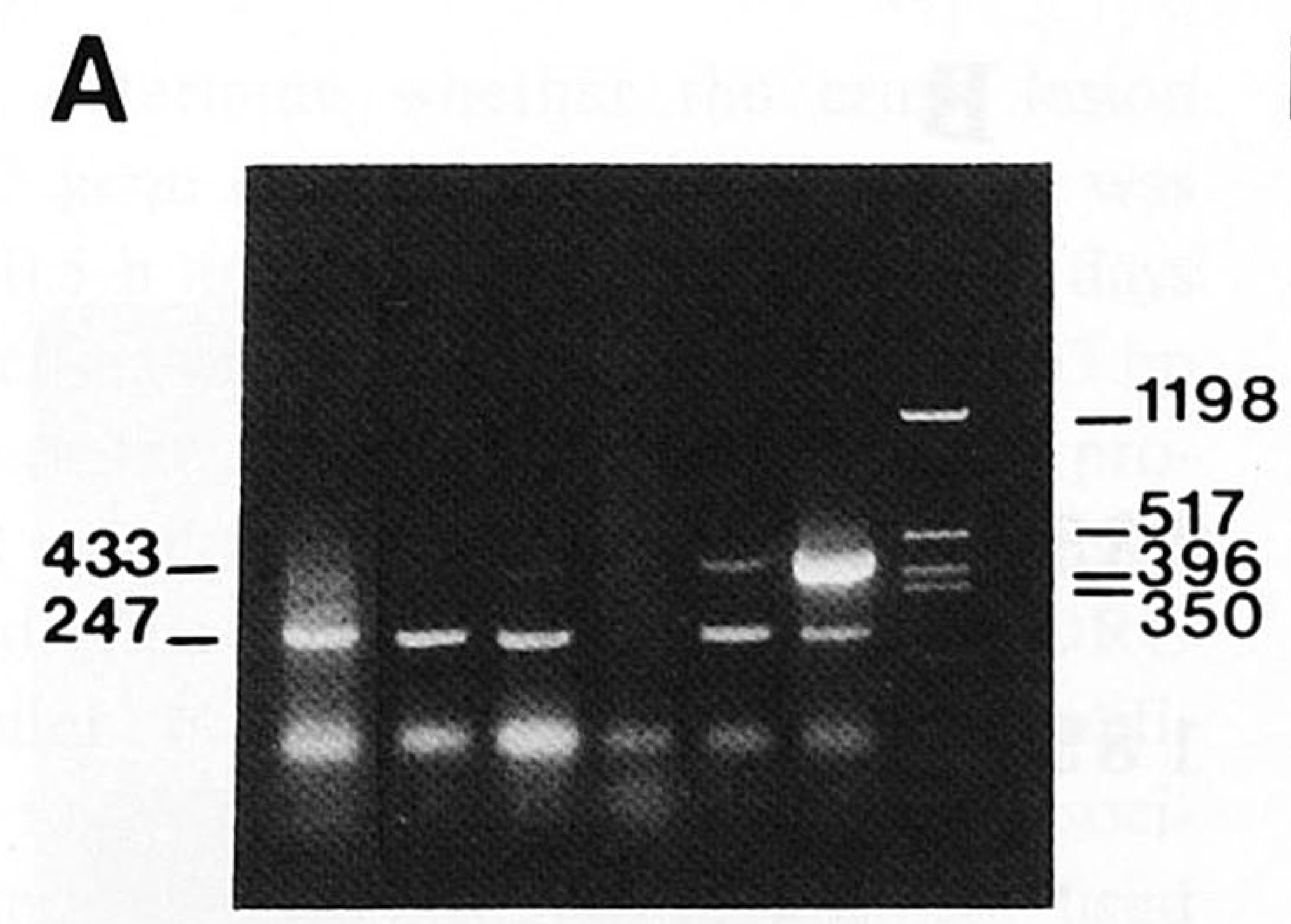

1223445567
B

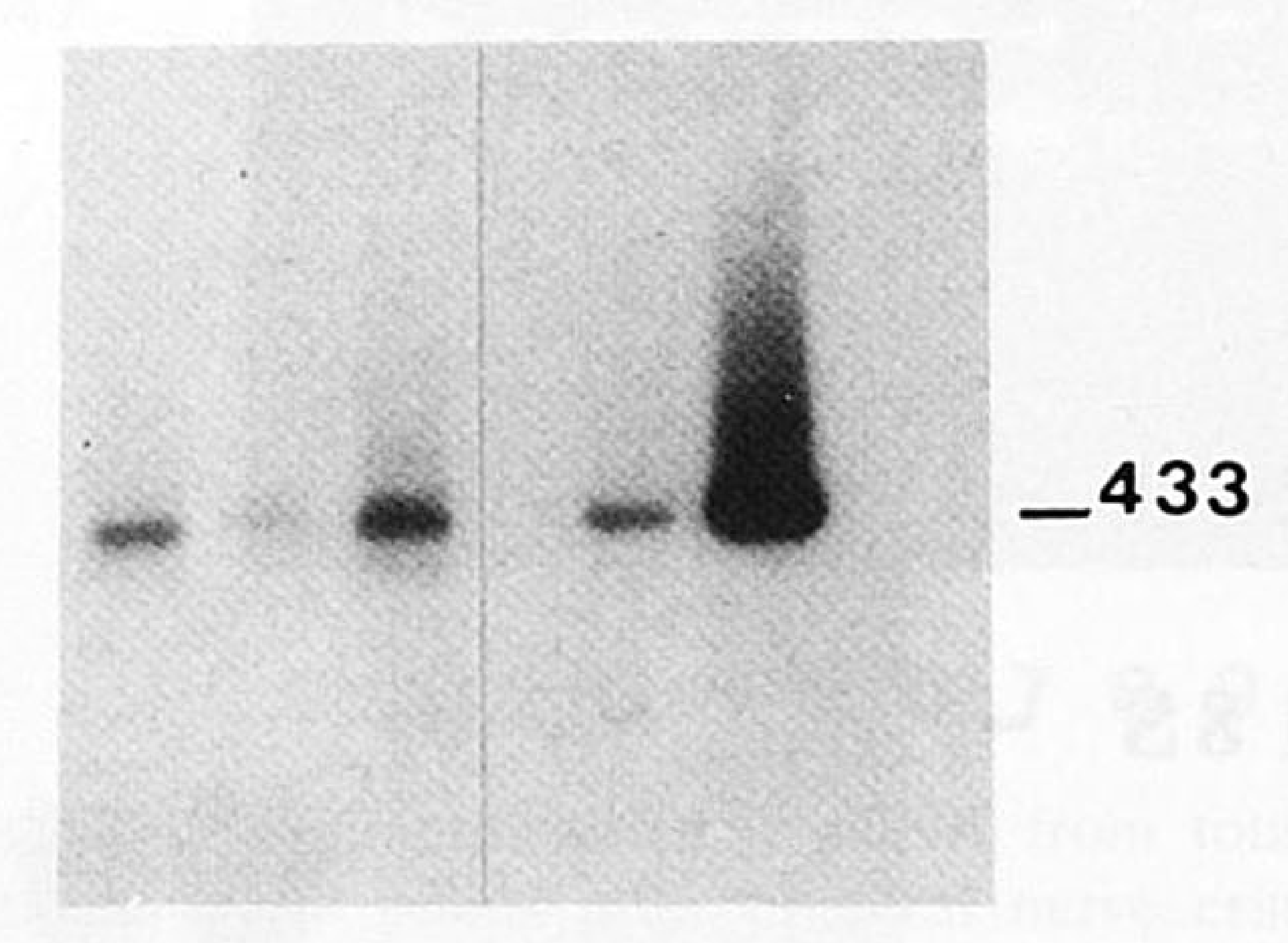

1233456

Fig. 2. PCR amplification of cDNA from total RNA of spinal cord, DRG and sciatic nerve of control rats. Total RNA was reverse transcribed into cDNA followed by PCR using two pairs of primers: one pair of primers specific for POMC cDNA resulting in an amplified POMC fragment of the expected size of $433 \mathrm{bp}$, and one pair of primers specific for B-50 cDNA resulting in an amplified B-50 fragment of the expected size of $247 \mathrm{bp}$. The products were analysed on a $2 \%$ agarose gel stained with ethidium bromide (A) and on a Southern blot hybridized with POMC probe I (B). Lane 1, spinal cord; lane 2, DRG; lane 3, sciatic nerve; lane 4, negative control; lane 5, hypothalamus; lane 6, pituitary; lane 7, molecular size marker (500 $\mu \mathrm{g}$ pGEM4 cut by HinfI). From all samples $15 \mu \mathrm{l}$ of a total of $50 \mu \mathrm{l}$ PCR reaction mixture was loaded on the gel in A. In B, $5 \mu \mathrm{l}$ of a total of $50 \mu \mathrm{l}$ PCR reaction mixture was loaded from the spinal cord, DRG and sciatic nerve and negative control samples whereas from the positive controls $0.25 \mu$ l of a total of $50 \mu$ l PCR reaction mixture was loaded on the gel of which the Southern blot was made. 
the high- and low-stringency protocol, each wash step was performed for $20 \mathrm{~min}$ at $42^{\circ} \mathrm{C}$. Blots were exposed for 2-8 days using Kodak $\mathrm{X}$-OMAT film with an intensifying screen (Amersham UK). Prior to reprobing, membranes were stripped by boiling in $0.01 \times$ SSC, $0.01 \%$ SDS for $20 \mathrm{~min}$.

Probes

For the hybridization of the Northern blots two different probes specific for POMC mRNA were used: a 139 bp rat POMC cDNA encoding part of exon 1, encoding exon 2 and part of exon 3 (nt 73 to 263, Fig 1 , probe II) and a 206 bp rat cDNA encoding part of exon 3 (nt 345-551, Fig. 1, probe III). For the hybridization of the Southern blot a 139 bp rat cDNA encoding part of exon 2 was used (nt 124-263) corresponding to the amplified portion of the POMC gene but not containing the sequence of the primers used for PCR (Fig 1, probe I). The B-50-specific probe was an 1130 bp B-50 cDNA isolated from clone $\mathrm{pGB} 0^{22}$. In order to determine the relative amount of RNA present in each lane blots were hybridized with a glyceraldehyde-3-phosphate dehydrogenase (GAPDH) probe. Labeling of the probe was performed with $\left[{ }^{32} \mathrm{P}\right] \mathrm{dCTP}$ using a random primed DNA labeling kit (Boehringer Mannheim) according to the protocol supplied with the kit.

\section{RESULTS}

The presence of a POMC transcript was investigated by PCR in DRG $\left(\mathrm{L}_{4-6}\right)$, spinal cord $\left(\mathrm{T}_{12}-\mathrm{L}_{1}\right)$ and at the crush site of the sciatic nerve in control rats and in rats at various times after crush $(0.5 \mathrm{~h}$ and $6 \mathrm{~h}$ and $1,2,4$ and 14 days). Specific POMC primers located in exon 1 (primer A) and exon 3 (primer B) of POMC mRNA were used to amplify the POMC transcript. Using these two primers only full length POMC transcripts containing exon 1, 2 and 3 will be amplified, thus excluding the $800 \mathrm{nt}$ POMC transcript. Fig. 2 shows the analysis of the PCR products amplified from cDNA obtained from spinal cord, DRG and sciatic nerve of control rats. A band of $433 \mathrm{bp}$, corresponding to the expected length of the amplification product of

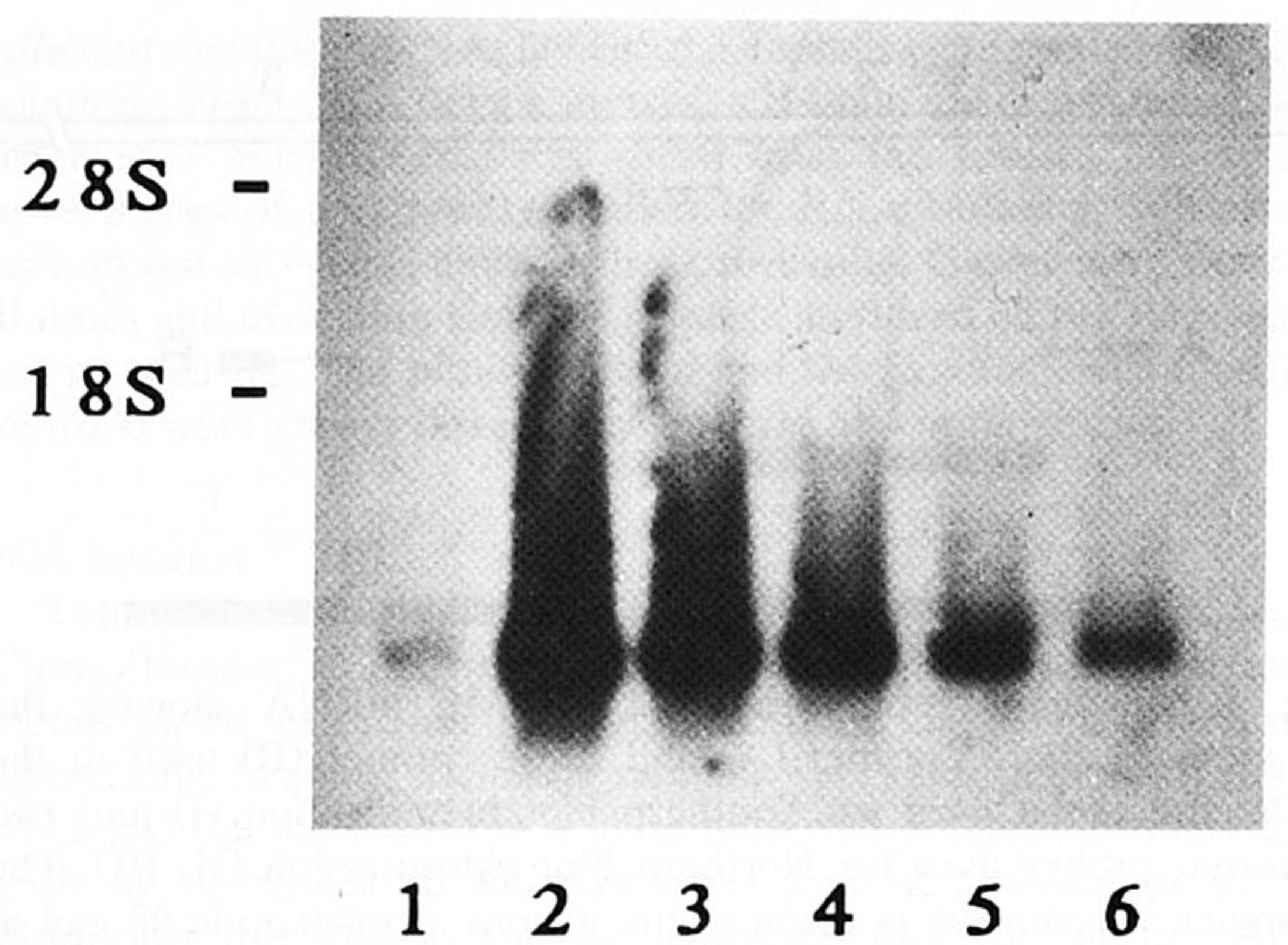

Fig. 3. Northern blot analysis of total RNA from rat hypothalamus and pituitary gland to evaluate the sensitivity of the Northern blot procedure. The membrane was probed with POMC probe III and washed to a final stringency of $0.1 \times \mathrm{SSC}, 0.1 \%$ SDS at $42^{\circ} \mathrm{C}$ and exposed to Kodak X-AR film for 4 days with an intensifying screen. Lane 1, hypothalamus (20 $\mu \mathrm{g}$ ); lane $2-6$, pituitary $0.5,0.25,0.125$, 0.06 and $0.03 \mu \mathrm{g}$ total RNA.

the POMC cDNA fragment, and a band of $247 \mathrm{bp}$, corresponding to the expected length of the amplification product of the B-50 cDNA, were observed with ethidium bromide staining in all samples (Fig. 2A). Southern blot analysis of the PCR products by hybridization with a POMC probe I revealed a band of 433 bp in all samples (Fig. 2B), indicating specific amplification of POMC transcripts. The amplification product of the B-50 transcript did not hybridize with the POMC probe.

The Northern blot analysis in Fig. 3 shows total RNA from the rat hypothalamus and a concentration range of total RNA from the rat pituitary in order to test the sensitivity. As little as $0.03 \mu \mathrm{g}$ of total RNA
A

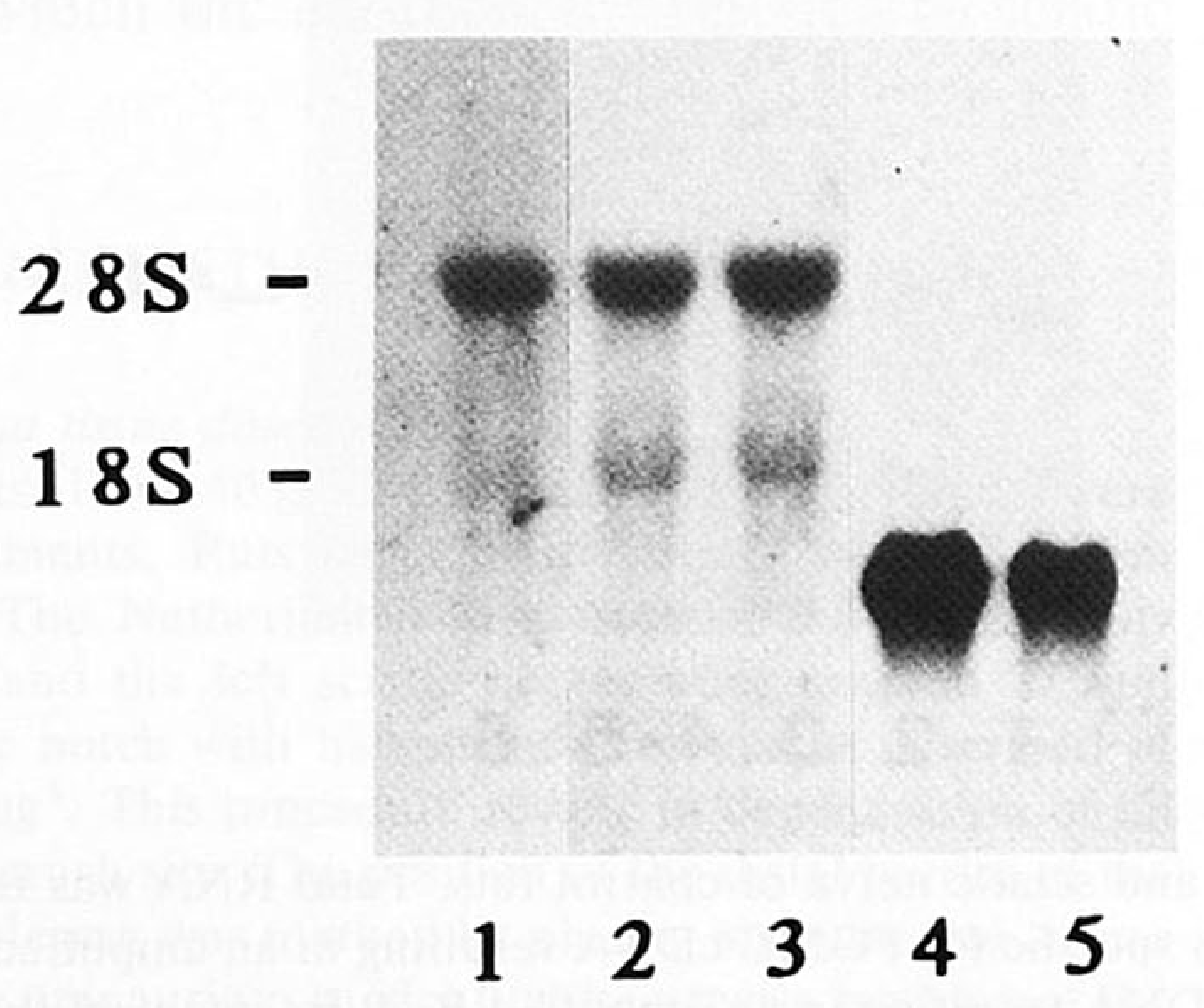

B

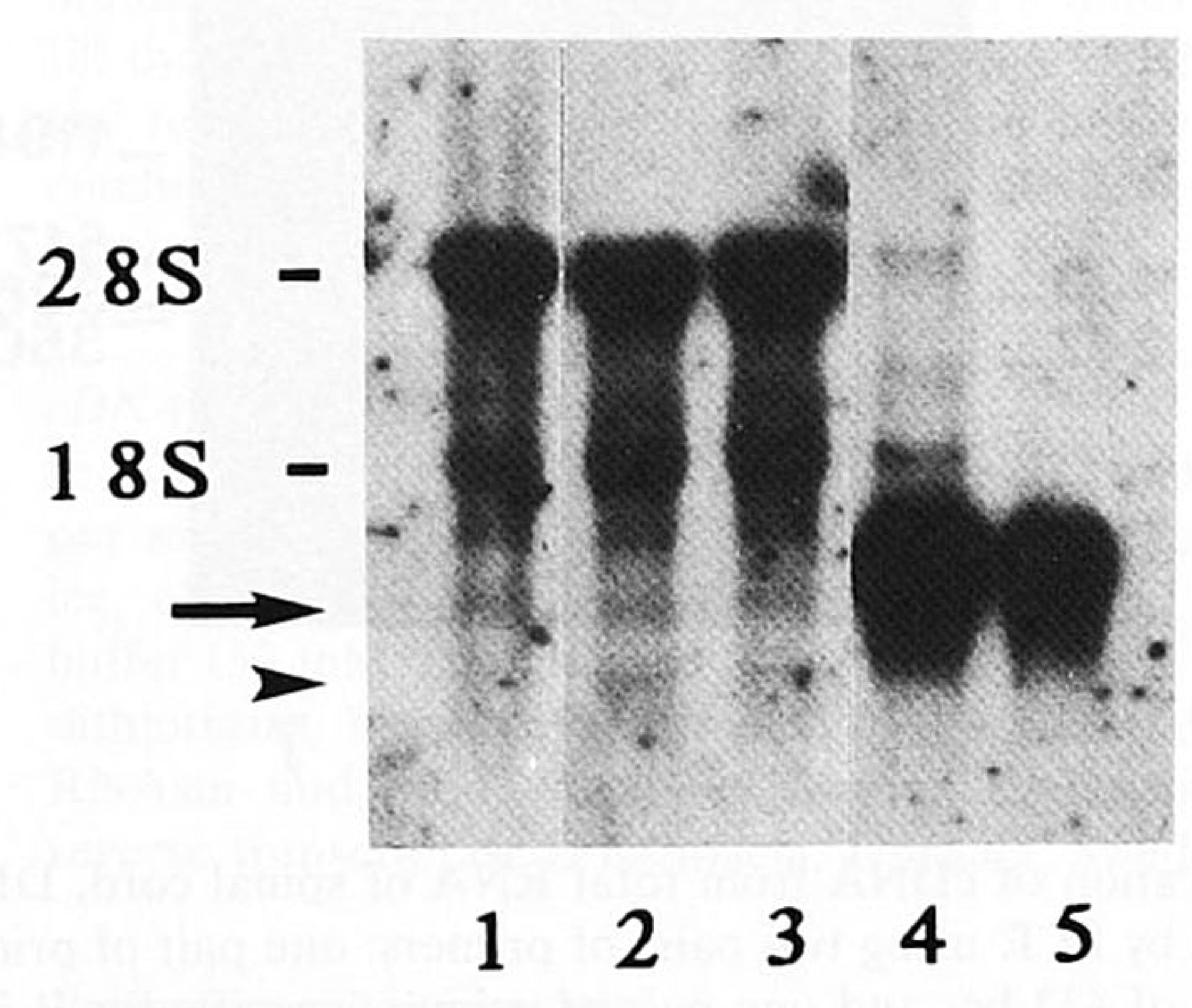

Fig. 4. Northern blot analysis of total RNA from spinal cord, DRG and sciatic nerve of control rats. The membrane was hybridized with POMC probe III. The stringency of the final wash step was $1 \times \mathrm{SSC}, 0.1 \%$ SDS at $42^{\circ} \mathrm{C}$. The membrane was exposed to Kodak X-AR films using an intensifying screen for 2 days (A) or 8 days (B). Lane 1, spinal cord (20 $\mu \mathrm{g})$; lane 2, DRG $(20 \mu \mathrm{g})$; lane 3, sciatic nerve (20 $\mu \mathrm{g})$; lane 4, pituitary (1 $\mu \mathrm{g}$ ); lane 5 , pituitary $(0.5 \mu \mathrm{g})$. In all tissues except the pituitary gland two faint bands corresponding to the $800 \mathrm{nt}$ (arrowhead) and $1200 \mathrm{nt}$ (arrow) POMC transcript are present after long exposure. The position of the ribosomal RNA (28S and 18S) is indicated. 
from rat pituitary was sufficient to produce a clearly visible POMC signal.

Total RNA isolated from spinal cord, DRG and the sciatic nerves of control rats was analysed by Northern blot analysis for the presence of the POMC transcript using POMC probe III. This exon 3 specific probe detects both the 800 nt and the 1200 nt POMC transcripts. No POMC signal could be detected after an exposure time of 2 days (Fig. 4A). Pituitary RNA showed a pronounced hybridization signal of $1200 \mathrm{nt}$ in accordance with the previously reported size of rat POMC mRNA in the pituitary gland. After an exposure time of 8 days, a number of bands were detected in all samples. One band of $1200 \mathrm{nt}$ comigrated with POMC mRNA in the pituitary gland and another band of $800 \mathrm{nt}$ was visible, probably representing the truncated form of the POMC transcript (Fig. 4B). The fact that these transcripts could only be visualized after an exposure time of 8 days with the use of an intensifying screen indicates that small amounts of POMC mRNA are present. Since the POMC signals obtained from total RNA samples were very weak it was necessary to further confirm the identity of the $1200 \mathrm{nt}$ and the 800 nt bands. Therefore poly $\left(\mathrm{A}^{+}\right)$RNA was isolated from spinal cord from control rats. The spinal cord was chosen because of the relatively large amounts of this tissue that could be obtained for the RNA extraction compared with the DRG and sciatic nerve tissue. Hybridization with a mixture of POMC probe II and POMC probe III followed by high stringency washing conditions resulted in two distinct bands of $1200 \mathrm{nt}$ and 800 nt (Fig. 5A). The same membrane was stripped and hybridized with POMC probe II. Only the $1200 \mathrm{nt}$ band was detected whereas the $800 \mathrm{nt}$ band was not visible (Fig. 5B).

In order to determine whether the crush lesion affected POMC gene expression, POMC mRNA was investigated at $0.5 \mathrm{~h}$ and $6 \mathrm{~h}$, and 1, 2, 4, and 14 days postlesion. No effect of the lesion on either the $433 \mathrm{bp}$ POMC-derived or the 247 bp B-50-derived bands produced by PCR from spinal cord, DRG and sciatic nerve was found. This is shown in Fig. 6 for the DRG samples. The failure to show an increase in the amplification product for B-50, a well-known growth-associated protein, indicates that the PCR protocol used does not allow reliable detection of quantitative differences between samples.

Using Northern blot analysis, no increase in the $1200 \mathrm{nt}$ nor in the $800 \mathrm{nt}$ band was observed at any of the post-lesion time points examined after probing with POMC probe III, indicating that the sciatic nerve crush did not affect the expression of the POMC gene (Fig. 7A). After stripping and reprobing the Northern blot

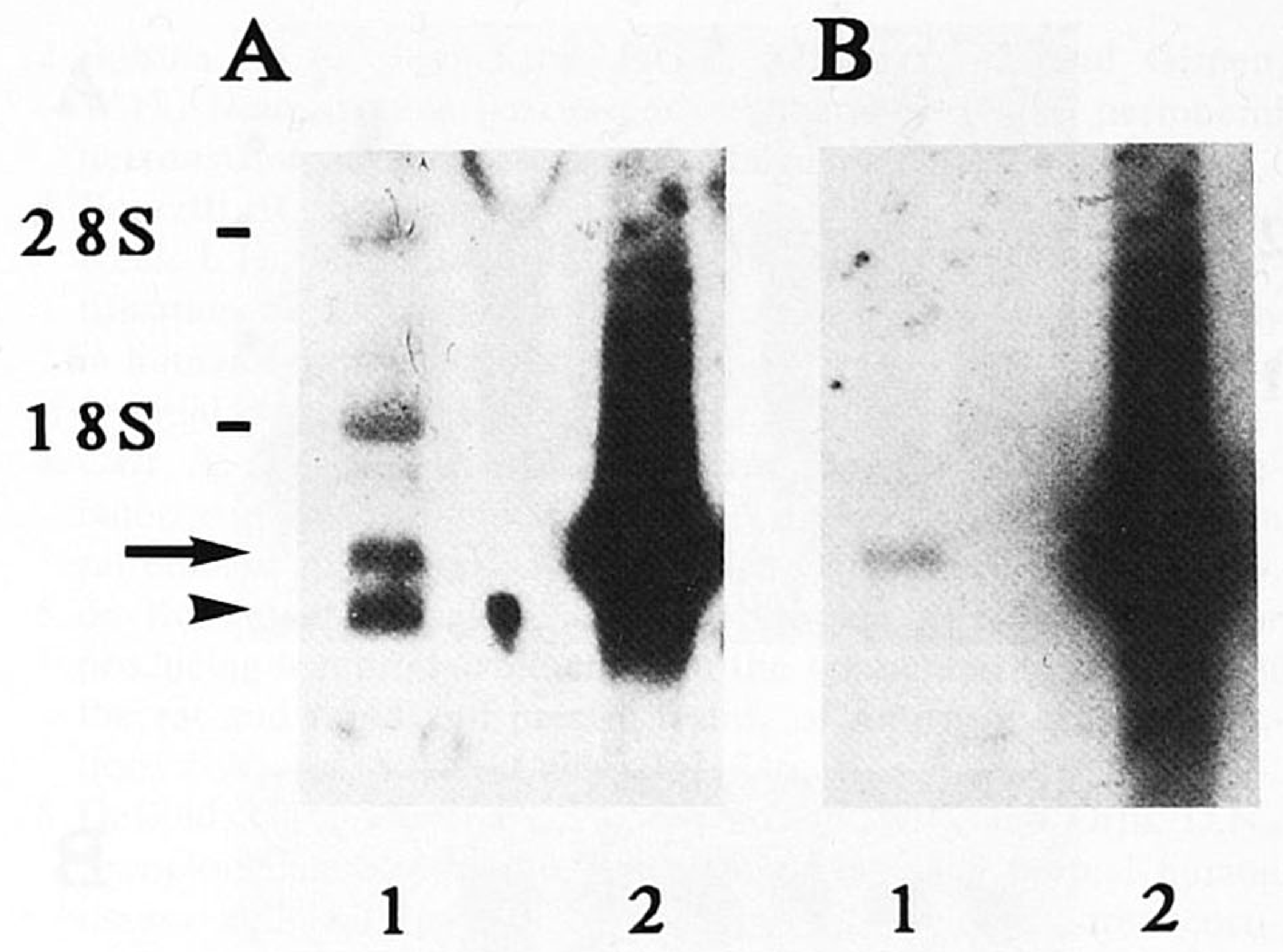

Fig. 5. Northern blot analysis of poly $\left(\mathrm{A}^{+}\right)$RNA from spinal cord of control rats hybridized with probe II and III (A) or with probe II (B). The membrane was washed to a final stringency of $0.1 \times$ SSC, $0.1 \%$ SDS and exposed to Kodak X-AR film for 5 days with an intensifying screen. Lane 1 , poly $\left(\mathrm{A}^{+}\right)$RNA from spinal cord $(20 \mu \mathrm{g})$; lane 2 , total RNA from pituitary $(1 \mu \mathrm{g})$. Note the presence of two transcripts ( $800 \mathrm{nt}$, arrowhead; $1200 \mathrm{nt}$, arrow) after probing the blot with POMC probe II and III and the absence of the $800 \mathrm{nt}$ band when only probe II was used. This demonstrates that the $800 \mathrm{nt}$ transcript

in the spinal cord is devoid of exon I and II of the POMC gene.

with the B-50 probe (Fig. 7B) an increase in B-50 mRNA expression was observed in DRG after crush. In Fig. 7C the blot is shown after hybridization with GAPDH, demonstrating the amount of RNA present in each lane. The increase in B-50 mRNA following nerve crush is in agreement with the previously reported growth associated expression of B-50 and

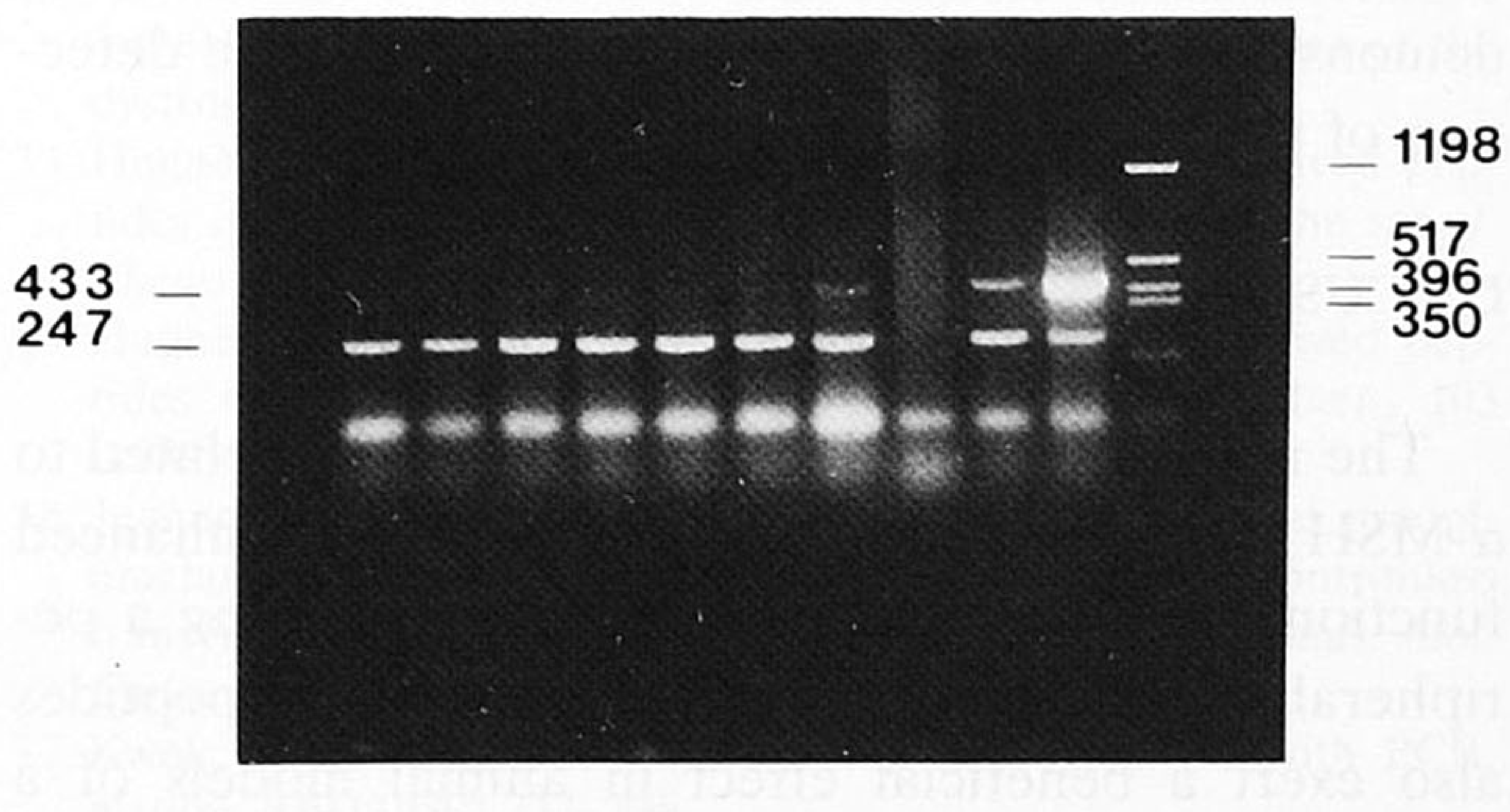

$\begin{array}{lllllllllll}1 & 2 & 3 & 4 & 5 & 6 & 7 & 8 & 9 & 10 & 11\end{array}$

Fig. 6. PCR amplification of cDNA from total RNA of DRG at different time points after bilateral nerve crush. Total RNA was reverse transcribed into cDNA followed by PCR using two pairs of primers: one pair of primers specific for POMC cDNA expected to result in an amplified POMC fragment of $433 \mathrm{bp}$, and one pair of primers specific for B-50 cDNA expected to result in an amplified B-50 fragment of $247 \mathrm{bp}$. The products were analysed on a $2 \%$ agarose gel stained with ethidium bromide. Lane 1, control DRG; lane $2-7,0.5$ h, 6 h, 1 day, 2 days, 4 days, 14 days after bilateral sciatic nerve crush respectively; lane 8 , negative control; lane 9, rat hypothalamus; lane 10, rat pituitary; lane 11, molecular size marker (500 $\mu \mathrm{g}$ pGEM4 cut by HinfI). From all samples, $15 \mu \mathrm{l}$ of the $50 \mu \mathrm{l}$ PCR reaction mixture was loaded on gel. 


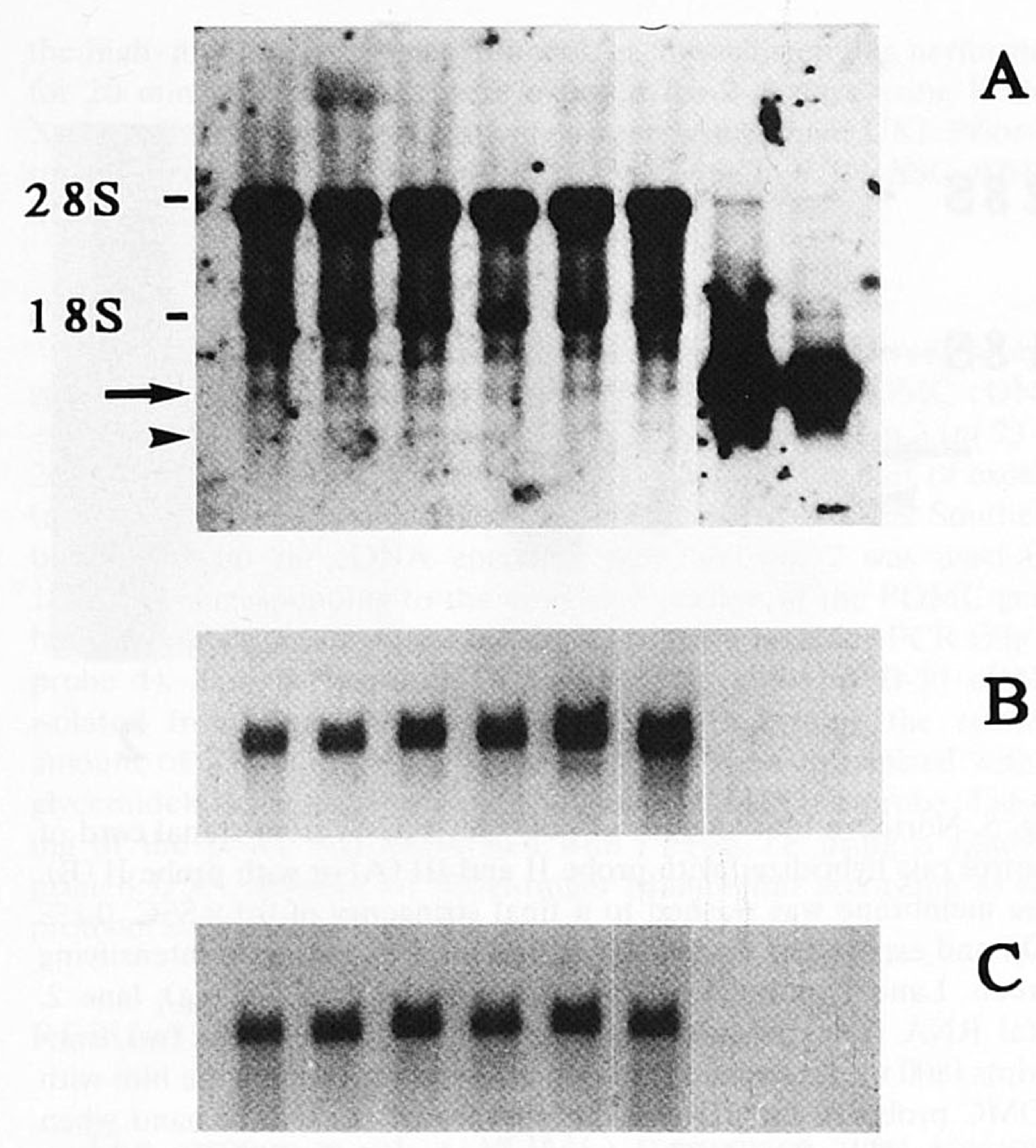

\section{$\begin{array}{llllllll}1 & 2 & 3 & 4 & 5 & 6 & 7 & 8\end{array}$}

Fig. 7. Northern blot analysis of totâl RNA from DRG at different timepoints after bilateral sciatic nerve crush probed with POMC probe III at a stringency of $1 \times \mathrm{SSC}, 0.1 \%$ SDS at $42^{\circ} \mathrm{C}(\mathrm{A}), \mathrm{B}-50$ probe at a stringency of $0.1 \times \mathrm{SSC}, 0.1 \%$ SDS at $42^{\circ} \mathrm{C}(\mathrm{B})$ or GAPDH probe at a stringency of $0.1 \times \mathrm{SSC}, 0.1 \%$ SDS at $42^{\circ} \mathrm{C}(\mathrm{C})$. Lane 1 , DRG $(20 \mu \mathrm{g})$ of control rats; lane 2-6, DRG $(20 \mu \mathrm{g}) 0.5 \mathrm{~h}, 6 \mathrm{~h}$ and 1,2 , and 14 days after bilateral crush of the sciatic nerve, respectively, lane 7 , pituitary $(1 \mu \mathrm{g})$; lane 8 , pituitary $0.5 \mu \mathrm{g})$. The arrow indicates the $1200 \mathrm{nt}$ and the arrowhead the $800 \mathrm{nt}$ POMC transcript in A. No increase in the $1200 \mathrm{nt}$ or the $800 \mathrm{nt}$ band (A) was observed following sciatic nerve injury, whereas the expression of- the B-50 mRNA (B) increased gradually.

demonstrated that our methodology enables the detection of the increased expression of this protein.

\section{DISCUSSION}

The neurotrophic action of neuropeptides related to $\alpha$-MSH has been demonstrated in terms of enhanced functional and morphological recovery following a peripheral nerve crush $^{2,28,33}$. In addition, these peptides also exert a beneficial effect in animal models of a variety of neuropathies including cisplatin, acrylamide and diabetic neuropathies ${ }^{12,27,30}$. Here we have examined whether upregulation of the gene coding for POMC, the prohormone of $\alpha-\mathrm{MSH}$ and ACTH, is part of an endogenous series of events set in motion in a nerve following injury. The results presented in this paper demonstrate that (1) two POMC transcripts, 800 nt and $1200 \mathrm{nt}$ in size, are expressed in minute quantities in spinal cord, DRG and in the sciatic nerve of non-lesioned adult control rats, and (2) the expression of these two POMC transcripts is not increased follow- ing a nerve crush lesion. Since POMC gene expression remains unchanged following a nerve crush we conclude that the upregulation of POMC-gene expression is not part of the repertoire of events that occur in a nerve following injury. The data suggest that nerve injury will not contribute to the formation of $\alpha$-MSH or related peptides in an injured nerve through enhanced POMC gene expression.

Using two primer sets, one designed to detect POMC and one specific for B-50, amplification products of the predicted size were detected in DRG, spinal cord and in the sciatic nerve. The correct size of the POMC product and the specific hybridization to a POMC probe convincingly demonstrate POMC mRNA expression in these tissues. In view of the extreme sensitivity of the PCR method, the problem of contamination between samples resulting in false positive amplification has been given great attention ${ }^{17,36}$. Using precautions as described in the methods, we never observed a signal in a negative control sample. Thus we are confident that the POMC signal in spinal cord, DRG and the sciatic nerve represents real POMC mRNA and cannot be due to cross contamination between pituitary and neuronal samples. Northern blot analysis support the conclusion that a full-length POMC mRNA exists in DRG, spinal cord and sciatic nerve.

A disadvantage of the PCR method used is that it does not allow reliable detection of quantitative differences between samples ${ }^{8,9}$. In our hands this is illustrated by the absence of an increase in B-50 PCR signal in DRG samples following sciatic nerve crush, whereas on Northern blots such an increase was visible (compare Fig. 6 to Fig. 7B). It is widely accepted that the expression of $\mathrm{B}-50$ is increased in injured peripheral neurons ${ }^{25,31}$. Hence, in order to determine the relative levels of POMC gene expression in damaged nerve we used Northern blot analysis. Differential hybridization of the two observed POMC-transcripts to probes specifically directed against exon 1 and 2 or directed to exon 3 of POMC demonstrates that: (1) the long transcript represents the full length POMC mRNA as found in the pituitary gland and (2) the short transcript is a truncated form of POMC mRNA containing a large portion of exon 3 as has been described in other peripheral tissues such as testis ${ }^{16}$. The expression of neither the long nor the short POMC transcript was upregulated following injury, whereas B-50 mRNA levels increased substantially as expected. The extensive timecourse of investigation, ranging from $0.5 \mathrm{~h}$ to 14 days following crush, virtually excludes that we have missed a transient increase in POMC expression occurring during very early or at relatively late stages of the repair process. 
$\alpha$-MSH and $\beta$-endorphin immunoreactivity has been found at the neuromuscular junctions in the soleus and extensor digitorum longus muscles and in the distal stump in normal adult rats following sciatic nerve transection ${ }^{14}$. Moreover, Edwards et al. ${ }^{10}$ have shown with a bioassay for $\alpha$-MSH that $\alpha$-MSH-like bioactive material is present in degenerating nerve stumps. During the development of the rat spinal cord POMC mRNA and POMC-derived neuropeptides were shown to be expressed transiently from E13-E15 days' gestation $^{4}$ suggesting a specific role for POMC in the development of the peripheral nervous system. Furthermore, immunocytochemical evidence of enhanced amounts of $\alpha$-MSH in the motoneurones of mice with inherited motoneurone disease ${ }^{15}$ or muscular dystrophy ${ }^{13}$, conditions in which the maturation of the endplates is delayed into adulthood and continued formation of new neuromuscular junctions is an ongoing process, suggest that enhanced production of melanocortins is associated with stages of active axonal growth. However, the current findings establish that upregulation of POMC gene expression does not occur in the neurons of the damaged sciatic nerve nor locally in proliferating Schwann cells or in infiltrating mononuclear blood cells at the site of the nerve crush $^{3,19,20,23,35}$. Thus the previously demonstrated induction of POMC-related immunoreactivity in damaged nerves is not due to increased POMC mRNA levels. Although we were not able to show an increase in POMC gene expression, we cannot exclude the possibility that there is increased production of biologically active peptides caused by (1) a more efficient translation of the low levels of POMC mRNA present in both neuronal cell bodies and non-neuronal cells at the crush site after crush or (2) altered precursor processing. However Verhaagen et al. have not been able to detect $\alpha$-MSH in crushed peripheral nerve with a radioimmunoassay ${ }^{32}$. Therefore we favour the view that the previously shown immunoreactive $\alpha$-MSH-like material in peripheral nerve is unrelated to POMC and could represent crossreactivity of $\alpha$-MSH antibodies with either NF150 or with an yet unidentified molecule that share a common epitope with $\alpha$-MSH ${ }^{29}$.

Acknowledgements. This work was supported by a grant of Organon International B.V., Oss, the Netherlands. We are grateful for the expert technical assistance of Jan Brakkee, Theo van Buren and Gerard Peek, and to Dr. J. Drouin for providing the rat POMC clone.

\section{REFERENCES}

1 Benowitz, L.I., Increased transport of 44,000 to 49,000 -Dalton acidic proteins during regeneration of the goldfish optic nerve: a two-dimensional gel analysis, J. Neurosci., 3 (1983) 2153-2163.
2 Bijlsma, W.A., Jennekens, F.G.I., Schotman, P. and Gispen, W.H., Neurotrophic factors and regeneration in the peripheral nervous system, Psychoneuroendocrinology, 9 (1984) 199-215.

3 Buzzetti, R., McLoughlin, L., Lavender, P.M., Clark, A.J.L. and Rees, L.H., Expression of pro-opiomelanocortin gene and quantification of adrenocorticotropic hormone-like immunoreactivity in human normal peripheral mononuclear cells and lymphoid and myeloid malignancies, J. Clin. Invest., 83 (1989) 733-737.

4 Carr, A. and Haynes, L.W., Transient appearance of proopiomelanocortin (POMC) messenger RNA and $\mathrm{N}$-terminal peptides in rat embryo spinal cord, Neurosci. Res. Commun., 3 (1988) 31-39.

5 de Koning, P., Brakkee, J.H. and Gispen, W.H., Methods for producing a reproducible crush in the sciatic and tibial nerve of the rat and rapid and precise testing of return of sensory function, J. Neurol. Sci., 74 (1986) 237-246.

6 DeBold, C.R., Menefeet, J.K., Nicholson, W.E. and Orth, D.N., Proopiomelanocortin gene is expressed in many normal human tissues and in tumors not associated with ectopic adrenocorticotropin syndrome, Mol. Endocrinol., 2 (1988) 862-870.

7 DeBold, C.R., Nicholson, W.E. and Orth, D.N., Immunoreactive proopiomelanocortin (POMC) peptides and POMC-like messenger ribonucleic acid are present in many rat nonpituitary tissues, Endocrinology, 66 (1988) 2648-2657.

8 Delidow, B.C., Peluso, J.J. and White, B.A., Quantitative measurement of mRNAs by polymerase chain reaction, Gene Anal. Techn., 6 (1989) 120-124.

9 Dickover, R.E., Donovan, R.M., Goldstein, E., Dandekar, S., Bush, C.E. and Carlson, J.R., Quantitation of human immunodefiency virus DNA by using the polymerase chain reaction, J. Clin. Microbiol., 28 (1990) 2130-2133.

10 Edwards, P.M., van der Zee, C.E.E.M., Verhaagen, J., Schotman, P., Jennekens, F.G.I. and Gispen, W.H., Evidence that the neurotrophic actions of $\alpha$-MSH may derive from its ability to mimic the actions of a peptide formed in degenerating nerve stumps, $J$. Neurol. Sci., 64 (1984) 333-340.

11 Ferreira, J.A., Carstens, M.E. and Taljaard, J.J.F., Quantitative determination of lymphocyte ACTH 1-39, Neuropeptides, 15 (1990) 11-15.

12 Gerritsen van der Hoop, R., de Koning, P., Boven, E., Neijt, J.P. Jennekens, F.G.I. and Gispen, W.H., Efficacy of the neuropeptide Org 2766 in the prevention and treatment of cisplatin-induced neurotoxicity in rats, Eur. J. Cancer Clin. Oncol., 24 (1988) $637-642$.

13 Haynes, L.W. and Smith, M.E., Presence of immunoreactive $\alpha$-melanotropin and $\beta$-endorphin in spinal motoneurones of the dystrophic mouse, Neurosci. Lett., 58 (1985) 13-18.

14 Hughes, S. and Smith, M.E., Proopiomelanocortin derived peptides in transected and contralateral motor nerves of the rat, $J$. Chem. Neuroanat., 2 (1989) 227-237.

15 Hughes, S. and Smith, M.E., Proopiomelanocortin-derived peptides in mice with motoneurone disease, Neurosci. Lett., 103 (1989) 169-173.

16 Jeannotte, L., Burbach, J.P.H. and Drouin, J., Unusual proopiomelanocortin ribonucleic acids in extrapituitary tissue: intronless transcripts in testes and long poly(A) tails in hypothalamus, Mol. Endocrinol., 1 (1987) 749-757.

17 Kwok, S. and Higuchi, R., Avoiding false positives with PCR, Nature, 339 (1989) 237-238.

18 Lacaze-Masmonteil, T., de Keyzer, Y., Luton, J.P., Kahn, A. and Bertagna, X., Characterization of proopiomelanocortin transcripts in human nonpituitary tissues, Proc. Natl. Acad. Sci. USA, 84 (1987) 7261-7265.

19 Lolait, S.J., Clements, J.A., Markwick, A.J., Cheng, C., McNally, M., Smith, A.I. and Funder, J.W., Proopiomelanocortin messenger ribonucleic acid and posttranslational processing of beta endorphin in spleen macrophages, J. Clin. Invest., 77 (1986) 1776-1779.

20 Lolait, S.J., Lim, A.T.W., Toh, B.H. and Funder, J.W., Immunoreactive $\beta$-endorphin in a subpopulation of mouse spleen macrophages, J. Clin. Invest., 73 (1984) 277-280.

21 McMaster, G.K. and Carmichael, G.G., Analysis of single- and double-stranded nucleic acids on polyacrylamide and agarose gels 
by using glyoxal and acridine orange, Proc. Natl. acad. Sci. USA, 74 (1977) $4835-4838$.

22 Nielander, H.B., Schrama, L.H., Van Rozen, A.J., Kasperaitis, M., Oestreicher, A.B., de Graan, P.N.E., Gispen, W.H. and Schotman, P., Primary structure of the neuron-specific phosphoprotein B-50 is identical to growth-associated protein GAP-43, Neurosci. Res. Commun., 1 (1987) 163-172.

23 Oates, E.L., Allaway, G.P., Armstrong, G.R., Boyajian, R.A., Kehrl, J.H. and Prabhakar, B.S., Human lymphocytes produce proopiomelanocortin gene-related transcripts, J. Biol. Chem., 263 (1988) 10041-10044.

24 Perry, V.H., Brown, M.C. and Gordon, S., Macrophage response to central and peripheral nerve injury, J. Exp. Med., 165 (1987) $1218-1223$

25 Skene, J.H.P. and Willard, M., Axonally transported proteins associated with axon growth in rabbit central and peripheral nervous system, J. Cell. Biol., 89 (1981) 96-103.

26 Smith, A.I. and Funder, J.W., Proopiomelanocortin processing in the pituitary, central nervous system, and peripheral tissues, Endocr. Rev., 9 (1988) 159-179.

27 Sporel-Özakat, R.E., Edwards, P.M., Gerritsen van der Hoop, R. and Gispen, W.H., An ACTH(4-9) analog, Org 2766, improves recovery from acrylamide neuropathy in rats, Eur. J. Pharmacol., 186 (1990) 181-187.

28 Strand, F.L., Rose, K.J., King, J.A., Segarra, A.C. and Zuccarelli, L.A., ACTH modulation of nerve development and regeneration, Prog. Neurobiol., 33 (1989) 45-85.

29 Tingstedt, J.E., Nielsen, J.B. and Larsson, L.I., Characterization of $\mathrm{MSH} / \mathrm{ACTH}-$ like immunoreactivity in sciatic nerves of Xeno- pus laevis by immunochemistry, western blotting and radioimmunoassay, Histochemistry, 95 (1990) 137-141.

30 Van der Zee, C.E.E.M., Gerritsen van der Hoop, R. and Gispen, W.H., Beneficial effect of Org. 2766 in treatment of peripheral neuropathy in streptozocin-induced diabetic rats, Diabetes, 38 (1989) 225-230.

31 Van der Zee, C.E.E.M., Nielander, H.B., Vos, J.P., Lopes da Silva, S., Verhaagen, J., Oestreicher, A.B., Schrama, L.H., Schotman, P. and Gispen, W.H., Expression of growth associated protein B-50 (GAP43) in dorsal root ganglia and the sciatic nerve during regenerative sprouting, J. Neurosci., 9 (1989) 3505-3512.

32 Verhaagen, J., Edwards, P.M. and Gispen, W.H., Damaged rat peripheral nerves do not contain detectable amounts of $\alpha-\mathrm{MSH}$, J. Neurosci. Res., 19 (1988) 14-18.

33 Verhaagen, J., Edwards, P.M., Jennekens, F.G.I. and Gispen, W.H., Pharmacological aspects of the influence of melanocortins on the formation of regenerative peripheral nerve sprouts, Peptides, 8 (1987) 581-584.

34 Verhaagen, J., Oestreicher, A.B., Edwards, P.M., Veldman, H., Jennekens, F.G.I. and Gispen, W.H., Light and electron microscopical study of phosphorylation B-50 following denervation and reinnervation of the rat soleus muscle, J. Neurosci., 8 (1988) $1759-1766$.

35 Westly, H.J., Kleiss, A.J., Kelley, K.W., Wong, P.K.Y. and Yuen, Newcastle disease virus infected splenocytes express the proopiomelanocortin gene, J. Exp. Med., 163 (1986) 1595-1600.

36 White, T.J., Arnheim, N. and Erlich, H.A., The polymerase chain reaction, Trends Neurosci., 5 (1989) 185-189. 